now, rather than smaller amounts on maintenance and renovation over the past decade, Yale is playing "a bit of catch-up" says Jeremiah Ostriker, provost of Princeton University. "I think they realized it was a necessity."

He adds that Yale will be able to compete in most areas of science. But catching up with some universities in engineering research may be more difficult. According to figures from the National Science Foundation, Johns Hopkins University spent \$213 million on engineering research and development in the financial year 1996; Yale spent \$6.6 million.

Princeton is investing $\$ 200$ million in construction, with about 60 per cent of it going towards new buildings, and a further $\$ 100$ million on faculty endowments and instrumentation, including \$55 million to set up a new genomics centre by 2002 . Harvard University is to spend $\$ 200$ million on science and engineering building and renovation over the next five years.

David Baltimore, president of the California Institute of Technology, says there is "a national trend" of universities constructing science buildings. The institute will spend $\$ 100$ million on a new biology building starting in the spring: the building will cost $\$ 40$ million, with the rest going on instrumentation, renovation and faculty endowments.

The US economy seems to be fuelling some of the building boom, with computer-industry entrepreneurs playing a major role. The Massachusetts Institute of Technology, for example, has begun fund-raising for a computerscience and artificial-intelligence complex. It has already received pledges worth $\$ 45$ million from two donors, including \$25 million from Bill Gates, the chairman of Microsoft. Paul Smaglik

\title{
NIH cancer researchers to get free access to 'OncoMouse'
}

Washington

After four years of negotiations between the US National Institutes of Health (NIH) and the pharmaceuticals company DuPont, NIH-funded scientists now have free use of the 'OncoMouse', a transgenic animal technology used to create mice that develop tumours.

OncoMouse is the second research tool that the company has made public in the past two years. The deals are a victory for scientists who have argued that broadly applicable techniques should be available without strings to not-for-profit researchers.

As a condition for the use of both tools, DuPont originally required licences, demanded 'reach-through' rights on any inventions resulting from their use, and placed limits on breeding and redistributing animals that were altered with them.

But the NIH and DuPont set the precedent for the OncoMouse agreement with a 1998 agreement eliminating such terms for not-for-profit research using Cre-lox, a technology that allows researchers to remove genes from specific cells and tissues (see Nature 394, 819; 1998).

The OncoMouse and Cre-lox agreements are very similar. Both also adhere to the NIH's principles for sharing research tools (see Nature 403, 10; 2000). Together they are "signposts for how similar problems might be solved", says Harold Varmus, president of the Memorial Sloan-Kettering Cancer Center in New York. Varmus helped negotiate with DuPont while he was NIH director, a position he held until the end of last year.

Varmus stresses that both agreements distinguish between products, such as restriction enzymes, that are "consumable", and

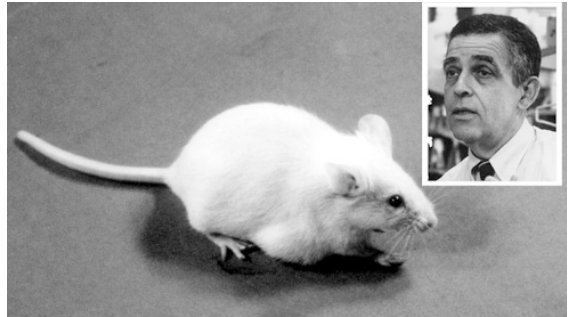

Public mouse: the NIH-DuPont deal has lifted a cloud of fear. Inset: Leder, OncoMouse creator.

techniques to make "things that replicate". Before the OncoMouse agreement, some cancer researchers operated under that distinction anyway, using the technique to develop cancer mouse models even though they had no licences or signed agreements with DuPont - a situation Varmus describes as "uncomfortable".

Those researchers feared that they were inadvertently infringing the patent, says Maria Freire, director of NIH's Office of Technology Transfer. She believes this agreement will lift that cloud of fear.

Both the deals differentiate between commercial and not-for-profit research. Commercially funded scientists must pay DuPont if they want to use either technique. But non-profit researchers, who can freely exchange animals altered with either technology, must alert DuPont if they distribute such animals to a commercial company.

The wider availability of the technique will allow more and better mouse models of cancer, says Phil Leder, a Harvard University researcher who developed the technology. "Cancer-prone mice are used in many research settings," he says. "This can only mean they can be more accessible." Paul Smaglik

\section{Canadian biomedical collaboration keeps on growing}

\section{Montreal}

The Medical Research Council of Canada (MRC) and the country's research-based pharmaceutical companies have announced significant increases for the second phase of a joint research programme, which has quadrupled in size since its introduction in 1993.

The collaboration's budget has risen from Can \$10 million (US\$7 million) at most each year at its beginning to more than Can $\$ 40$ million today.

Phase I has generated Can\$237 million for health research. The second five-year phase will introduce several new and improved programmes, and the proportion of funding by the partners will change.

For training and salary awards, the MRC contributed Can $\$ 1$ for every Can $\$ 4$ from industry in the first phase; each will contribute half the cost in the second phase. In funding operating grants, the MRC also contributed Can $\$ 1$ for every Can $\$ 4$ from industry, but its second-phase contribution will be Can $\$ 2$ for every Can $\$ 1$ from industry.

New operating fellowship awards of up to Can\$49,000 a year for three years will be available for scientists in clinical investigation and interdisciplinary research, plus up to Can\$30,000 in research allowances in the first year. University-industry research chairs will also be created, at a cost of up to Can\$140,000 a year plus operating funds.

Funding ratios for clinical trials have been left at Can $\$ 1$ from MRC to Can $\$ 4$ from industry. But provision will be made for 'add-on studies' to allow additional research, with infrastructure costs being absorbed by the larger study.

Marc Lepage, a spokesman for the MRC, says that, although it is impossible to estimate the total amount that the second phase of the programme will generate, the MRC would be "very disappointed" if they "only made \$237 million”.

David Spurgeon 